\title{
Can silicon partially alleviate micronutrient deficiency in plants? a review
}

\author{
Lourdes Hernandez-Apaolaza
}

Received: 8 May 2014/ Accepted: 30 June 2014/Published online: 11 July 2014

(C) Springer-Verlag Berlin Heidelberg 2014

\begin{abstract}
Silicon protects plants against various biotic and abiotic stresses, including metal toxicity. Under a high metal concentration, Si can externally decrease metal availability to the plant by its precipitation in the growth media, and $\mathrm{Si}$ also affects the metal distribution inside the plant, diminishing the damage. Could $\mathrm{Si}$ also protect plants against metal deficiency stress? Recently, the physiological role of $\mathrm{Si}$ in relation to micronutrients deficiency symptoms has been assessed in several plant species in hydroponics. In cucumber, $\mathrm{Si}$ supply mitigated the symptoms of $\mathrm{Fe}$ deficiency, but this effect was not clear under $\mathrm{Zn}$ - or Mndeficiency conditions. The main factor controlling this beneficial effect seems to be the Si contribution to the formation of metal deposits in the root and/or leaves apoplast and its role in their following remobilization when required. The enhancement of the content of long-distance transport molecules (such as citrate) due to $\mathrm{Si}$ addition should also contribute to the metal transport from root to shoot, which will diminish deficiency symptoms.
\end{abstract}

Keywords Silicon $\cdot$ Micronutrients deficiency $\cdot$ Storage pools $\cdot$ Remobilization $\cdot$ Metal distribution

\section{Introduction}

Silicon is the second most abundant element in the earth and it has a profuse presence in the soil as part of one of its main components, the clay minerals. Its concentration in

L. Hernandez-Apaolaza ( $\square)$

Agricultural Chemistry Department, Sciences Faculty, Autonomous University of Madrid, Francisco Tomás y Valiente no 7, 28049 Madrid, Spain

e-mail: lourdes.hernandez@uam.es the soil solution varies from 0.1 to $1.4 \mathrm{mM}$ (Marschner 1995) and plants absorb it as silicic acid $\left[\mathrm{Si}(\mathrm{OH})_{4}\right]$, at $\mathrm{pH}$ below $9(\mathrm{pka}=9.8)$. As a consequence, all plants grown in soil contain some $\mathrm{Si}$ in their tissues. However, repeated cropping and the application of chemical fertilizers have depleted the amount of Si that is available to plants (Ma and Yamaji 2006). Silicon deficiency in soils is now recognized as a limiting factor for crop production, especially for Si-accumulating plants such as rice and sugarcane and Si fertilizers are routinely applied to enhance these crop yields (Ma and Yamaji 2006).

Higher plants have been classified based on their ability to take up Si as: active Si accumulators, passive accumulators and Si rejective plants (Takahashi et al. 1990) and differ greatly in their ability to accumulate $\mathrm{Si}$, ranging from 0.1 to $10.0 \% \mathrm{Si}$ (dry weight) (Epstein 1999). The differences in $\mathrm{Si}$ accumulation between species have been attributed to differences in the Si uptake ability of the roots. The mechanism that controls this uptake has been studied in different plants, such as rice, a typical $\mathrm{Si}$ active accumulator; cucumber, which is, among other dicots, the one that accumulates higher Si concentrations in shoots (Liang et al. 2005a, b) and tomato, that accumulates low levels of Si (Mitani and Ma 2005). It was found that transportation of $\mathrm{Si}$ from the external solution to the cortical cells is mediated by a similar energy-dependent transporter in all three species; however, the $V_{\max }$ differs with plant species (i.e., rice $>$ cucumber $>$ tomato), suggesting that the density of the transporter differs among plant species (Mitani and Ma 2005). The high Si accumulation in rice has been demonstrated to be achieved by high expression of two $\mathrm{Si}$ transporters: Lsi1 (Low silicon 1) and Lsi2. Lsi1 belongs to a Nod26-like major intrinsic protein (NIP) subfamily of aquaporin-like proteins and functions as a $\mathrm{Si}$ permeable channel (Ma et al. 2006), while Lsi2 belongs to a putative 
anion transporter and functions as an efflux Si transporter (Ma et al. 2007). Both Lsi1 and Lsi2 are localized at different sites at the plasma membrane of both exodermis and endodermis cells of the roots (Ma et al. 2006, 2007). A concerted work of these two transporters produces an effective flow of $\mathrm{Si}$ in the exodermis and endodermis to override the barrier of Casparian strips (Ma et al. 2006, 2007). Similar findings were observed in wild and cultivated rice (Mitani-Ueno et al. 2013). In addition to rice, similar Si transporters were found in other grasses such as maize, barley and wheat (Mitani et al. 2009a, b; Chiba et al. 2009; Montpetit et al. 2012; Yamaji et al. 2012).

Following uptake by the roots, $\mathrm{Si}$ is translocated to the shoot via xylem and major differences between species appear on this xylem-loading step. Silicon concentration in rice xylem sap is 20 -fold higher than in cucumber, due to a transporter-mediated xylem loading, in comparison to the passive diffusion mechanism found in cucumber and tomato (Mitani and Ma 2005). Therefore, xylem loading has been defined as the key step in Si active accumulation in rice. The much lower accumulation of $\mathrm{Si}$ in cucumber and tomato might be explained by a lower density of the transporter to transport $\mathrm{Si}$ from the external solution to the cortical cells, and a defective or absence of transporter to transport Si from cortical cells to the xylem.

The major form of $\mathrm{Si}$ in the xylem has been identified as monomeric silicic acid (Casey et al. 2004; Mitani et al. 2005). In shoot, silicic acid is further concentrated through loss of water (transpiration) and is polymerized. The process of Si polymerization converts silicic acid to colloidal silicic acid and finally to silica gel $\left(\mathrm{SiO}_{2} \cdot \mathrm{nH}_{2} \mathrm{O}\right)$ with increasing silicic acid concentration (Ma and Takahasi 2002). In rice plants, more than $90 \%$ of total $\mathrm{Si}$ in the shoot is present in the form of silica gel, and a similar pattern of accumulation is observed in cucumber leaves, although the total Si concentration of cucumber is much lower than that of rice (Ma and Yamaji 2006). The distribution of $\mathrm{Si}$ in the shoot is then controlled by transpiration and due $\mathrm{Si}$ is not mobile within the plant; it tends to accumulate in older tissues (Ma and Yamaji 2006). Silicon transporters for xylem unloading and distribution of $\mathrm{Si}$ were also identified in rice (Yamaji et al. 2008; Yamaji and Ma 2009). Re-uptake of Si from the xylem is performed by Lsi6, which is an influx transporter for silicic acid and is mainly localized in the xylem parenchyma cells of the leaf blades and sheaths of rice (Yamaji and Ma 2009).

The Si depositions protect plants from multiple abiotic and biotic stresses (Ma and Takahasi 2002; Ma and Yamaji 2006; Datnoff et al. 2001). This element can increase plant resistance to pathogens and insects (Fauteux et al. 2005; Savant et al. 1997) as well as against chemical stresses (nutrient imbalance, salt) and physical stresses (freezing, lodging, radiation, high temperature, drought) (Ma and
Yamaji 2006; Ma 2004). Two mechanisms for Si-enhanced resistance have been proposed. One is that $\mathrm{Si}$ acts as a physical barrier; $\mathrm{Si}$ is deposited beneath the cuticle to form a cuticle-Si double layer (Fauteux et al. 2005) and this layer can mechanically impede penetration by pathogens and insects and, thereby, disrupt the infection process. The composition of silica deposits has been identified as metal and silicon precipitates (Neumann and zur Nieden 2001; da Cunha and do Nascimento 2009), which will contribute to metal detoxification or as a metal source when required. Another mechanism proposed recently is that soluble $\mathrm{Si}$ acts as a modulator of host resistance to pathogens, by stimulating some mechanisms of the defense reaction (Fauteux et al. 2005).

Moreover, the beneficial effects of Si addition on plant development have been described for several plant species (Adatia and Besford 1986; Mitsui and Takatoh 1963; Emadian and Newton 1989; Li et al. 1989; Ma 2004). As an example, Si-treated cucumber plants (Cucumis sativus $c v$. Corona) have darker green and thicker leaves with greater dry weight per unit area than leaves from untreated plants (Adatia and Besford 1986). Wilting and senescence of leaves were delayed under Si supply, although fruit yield was not increased after the addition of this element (Adatia and Besford 1986). High accumulation of $\mathrm{Si}$ in rice has been demonstrated to be necessary for a healthy growth and high and stable production. For this reason, Si has been recognized as an "agronomically essential element" and silicate fertilizers have been applied to paddy soils (Ma 2004). However, a limited Si benefit was observed in several species such as orange trees grown in solution culture (Wutscher 1989). In general, its beneficial effects are usually expressed more clearly when plants are subjected to various abiotic and biotic stresses.

\section{Silicon and micronutrient deficiency}

Several studies could be found in the literature about the effect of Si on micronutrient toxicity. However, its effect on metal deficiency has been less studied, although recently several authors focus their research on this topic (Gonzalo et al. 2013; Pavlovic et al. 2013; Bityutskii et al. 2014). The effect of $\mathrm{Si}$ on micronutrient toxicity has been explained by either internal or external effects. Externally, $\mathrm{Si}$ amelioration of metal toxicity in plants has been explained by the Si-mediated metal precipitation in the growth media, which decreases the toxic metal availability for plants in soils or in nutrient solution (Ma 2004; Fu et al. 2012; da Cunha et al. 2008; Liang et al. 2005a, b). However, in some crops, metal immobilization in non toxic forms inside roots or leaves have also been proposed, among other hypothesis, as a plant mechamism to decrease 
metal toxicity. This immobilization takes place through a Si-mediated metal precipitation or a Si-mediated metal bond to the plant cell walls (Neumann and zur Nieden 2001; Liang et al. 2007).

Metal immobilization could not only be considered as a defense against different metal toxicities, but a micronutrient source for plant nutrition under deficiency conditions, because these pools are also formed when plants are grown at non-toxic metal concentrations (Bienfait et al. 1985; Briat et al. 1995). Does Si addition increase the formation of metal pools, which will be remobilized under deficient conditions? Moreover, a different metal distribution inside the plant due to the $\mathrm{Si}$ presence is also a general evidence for the four micronutrients under toxicity conditions. Could $\mathrm{Si}$ ameliorate plant micronutrient deficiency symptoms through a change of metal distribution inside plantincreasing micronutrient content in seeds and fruits, which will benefit yield and crop quality under deficiency conditions?

During plant senescence or during deficiency periods, remobilization of stored nutrients has been observed from vegetative tissues, such as leaves and stems, to seeds, fruits or even young leaves. These provide a source-sink relationship that leads to a more efficient use of the absorbed nutrient. For example, an increase in the remobilization rate of $\mathrm{Fe}$ and $\mathrm{Zn}$ in plants under these micronutrients shortage has been demonstrated (Waters et al. 2009). However, the amount of remobilized micronutrient is not enough to complete the total seed requirements, therefore plants need to continue absorbing and transporting metals from the media to the seed.

\section{Iron deficiency}

Iron deficiency is a very important plant nutritional disorder worldwide, especially for plants grown in calcareous soils. In these soils, calcium carbonate is a major component and keeps soil solution $\mathrm{pH}$ at 7.5-8.5, due to a high bicarbonate concentration. Iron oxides typically control $\mathrm{Fe}$ solubility in the soil solution, which is limited to around $10^{-10} \mathrm{M}$ in the case of calcareous soils. This concentration is not enough for a plant optimal growth $\left(10^{-8} \mathrm{M}\right)$ (Römheld and Marschner 1986), therefore deficiency symptoms appear, such as interveinal leaf yellowing or necrosis; moreover, crop yield and quality could be severely reduced.

To overcome Fe deficiency, efficient plants develop different strategies. Dicots and non-graminaceous plants increase the roots $\mathrm{Fe}(\mathrm{III})$ reduction power through an $\mathrm{Fe}(\mathrm{III})$-chelate reductase coupled with an increase on the biosynthesis of a $\mathrm{Fe}(\mathrm{II})$ transporter, also a rhizosphere acidification and the release of phenolic compounds were described as tools to increase the available $\mathrm{Fe}$ in the rhizosphere (strategy I) (Hindt and Guerinot 2012). Graminaceous plants (strategy II) release the rhizospherespecific Fe-chelating agents, called phytosiderophores, to solubilize Fe from the soils (Hindt and Guerinot 2012). In plants from both strategies, insoluble $\mathrm{Fe}$ pools might be detected in the apoplast (Bienfait et al. 1985; Briat et al. 1995) and genotypes that form larger Fe apoplastic pools are less susceptible to develop $\mathrm{Fe}$ chlorosis symptoms (Longnecker and Welch 1990). As an example, Arabidopsis plants growing with different $\mathrm{Fe}$ concentrations in the nutrient solution try to maintain the same Fe concentration in shoots (Baxter et al. 2008) by the remobilization of stored Fe pools within the plant (Jin et al. 2007; García-Mina et al. 2013). Like ferritin in the cell, Fe in these pools could be mobilized when needed and some of the mechanisms previously described in the strategies I and II are involved in their solubility (Bienfait et al. 1985). The role of phenolics on the root $\mathrm{Fe}$ pools' remobilization in red clover was studied (Jin et al. 2007) and it has been found that they delayed the activation of $\mathrm{Fe}$ (III)-chelate reductase and diminished rhizospheric acidification (Jin et al. 2007), probably due to its contribution to the iron pools remobilization.

As for the other micronutrients, several studies could be found in the literature about the effect of Si on Fe toxicity. However, its effect on Fe deficiency has been less studied (Gonzalo et al. 2013; Pavlovic et al. 2013; Bityutskii et al. 2014) especially in strategy I plants, and the reported experimental conditions were different among references. Iron toxicity has been effectively alleviated in rice after Si addition (Ma 2004; Fu et al. 2012) mainly by an increase in the iron precipitation in the growth media or at root surfaces (iron plaque). Iron plaque is mainly formed by ferric hydroxides, primarily lepidocrocite and goethite, which have a high capacity to bind metal ions such as $\mathrm{Zn}^{2+}$, $\mathrm{Cd}^{2+}$, and $\mathrm{Cu}^{2+}$ (Chen et al. 1980a, b). A proposed hypothesis indicates that $\mathrm{Si}$ addition increases the oxidation capacity of rice roots and increases Fe oxidations to ferric insoluble compounds (Fu et al. 2012; Okuda and Takahashi 1962), which will form the Fe plaque. Although oxidebound ions in soils are often relatively unavailable to plants, the root-plaque-bound ions may become available for plant uptake if the plant exudes phytosiderophores that chelate the metal or simply dissolve the iron oxide, making the metal soluble again in the immediate vicinity of the root (Zhang et al. 1998). Some iron oxides were also accumulated inside cells and in apoplast ( $\mathrm{Fu}$ et al. 2012). $\mathrm{Fu}$ et al. (2012) also concluded that $\mathrm{Si}$ increased $\mathrm{Fe}$ transport from root to shoot, although Fe treatment might not influence $\mathrm{Si}$ uptake and transportation. It was also suggested that the increase expression of Si transporters after $\mathrm{Si}$ addition might influence Fe uptake and translocation (Fu et al. 2012) and will benefit $\mathrm{Fe}$ nutrition under 
deficiency conditions. These authors also show that the Si addition to the media reduced the $\mathrm{Fe}$ concentration on iron plaque in rice, due to its transport to shoot.

In general, $\mathrm{Si}$ effect on $\mathrm{Fe}$ deficiency is tested after a previous sufficiency period in which plants are treated with enough $\mathrm{Fe}$ and different $\mathrm{Si}$ doses. The external precipitation of the metal due to the solution $\mathrm{pH}, \mathrm{Si}$ addition, $\mathrm{Fe}$ source, etc., is a key factor to elucidate between the external oxide precipitation and the contribution of internal plant mechanism. In (nutrient or soil) solution, all forms of solid silica, crystalline and amorphous, are dissolved to a limited extent in water around $\mathrm{pH}$ 7.0, at different rates depending on phase, surface area, etc. At this $\mathrm{pH}$, the equilibrium concentration of monomeric silicic acid $\left[\mathrm{H}_{4} \mathrm{SiO}_{4}\right.$ or $\left.\mathrm{Si}(\mathrm{OH})_{4}\right]$ is less than $2 \mathrm{mM}$ and above this, polycondensation takes place and colloidal particles could be formed (Birchall 1990). The nutrient solution $\mathrm{pH}$ used to study $\mathrm{Fe}$ and other micronutrients deficiency is normally around 7.5-8.0, in contrast to the acidic $\mathrm{pH}$ used in metal toxicity studies ( $\mathrm{pH} 5.0-6.5$ ); therefore, only $\mathrm{Si}$ concentrations below $2 \mathrm{mM}$ could be tested. Usually, $\mathrm{Fe}(\mathrm{III}) \mathrm{EDTA}$ and $\mathrm{FeSO}_{4}$ are used as $\mathrm{Fe}$ sources in nutrient solution, but the low-stability constants make them not adequate to be used at $\mathrm{pH}$ above 6.5 (Fig. 2); and stronger chelates are required (Table 1). Coupled with this, a $\mathrm{Fe}$ decrease from the nutrient solution was expected due to its co-precipitation with $\mathrm{Si}$ or its adsorption onto the silicates surfaces (Gonzalo et al. 2013). Moreover, nutrient/soil solution redox potential plays also a fundamental role on $\mathrm{Fe}$ stability in solution. When $\mathrm{FeSO}_{4}$ is added to pots, part of the $\mathrm{Fe}$ could be readily absorbed by the plant as $\mathrm{Fe}^{2+}$, but as the nutrient solution was constantly aerated or due to the radial oxygen loss detected in rice roots under anaerobic conditions (Evans 2004), $\mathrm{Fe}^{2+}$ is transformed into $\mathrm{Fe}(\mathrm{III})$ forms, and the precipitation of iron as oxihydroxides is expected. Conversely, Fe(III)EDTA maintains enough Fe in solution at $\mathrm{pH} 6.5$ (Fig. 2), but its stability is low at higher $\mathrm{pH}$; and $\mathrm{Si}$ addition probably increased $\mathrm{pH}$ and may lead to Fe precipitation. As mentioned, $\mathrm{Fe}$ and $\mathrm{Si}$ could also co-precipitate, as $\mathrm{Fe}(\mathrm{III})$-silicates, or $\mathrm{Si}$ may precipitate as negatively charged silica particles (Currie and Perry 2007), in which the positively charged Fe may be bind, with the consequent $\mathrm{Fe}$ depletion from the solution. A high concentration of $\mathrm{Cu}$ in the soil solution also plays a major role on Fe(III)EDTA stability (Fig. 1) by reducing the soluble Fe. All these facts may cause an additional increase on Fe deficiency and the effect of the $\mathrm{Si}$ addition could be disguised. In contrast, when $\mathrm{Fe}$ is supplied as a stronger chelate, such as $\mathrm{Fe}$ (III)-HBED ( $N, N$-bis (2hydroxybenzyl) ethylenediamine- $N, N$-diacetic acid), no $\mathrm{Fe}$ depletion in the nutrient solution was observed at any $\mathrm{Si}$ rate (Gonzalo et al. 2013). This difference is related to the lower stability constant of Fe(III)-EDTA compared to
Table 1 Stability constants of the Fe(III) chelates of HBED ( $N, N$-bis (2-hydroxybenzyl) ethylenediamine- $N, N$-diacetic acid), EDDHA (ethylenediaminedi(o-hydroxyphenylacetic acid) (racemic and meso isomers) and EDTA

\begin{tabular}{lllll}
\hline & \multicolumn{2}{l}{$\log K$} & & \\
\cline { 2 - 5 } & HBED $^{\mathrm{a}}$ & rac-EDDHA $^{\mathrm{b}}$ & meso-EDDHA $^{\mathrm{b}}$ & EDTA $^{\mathrm{c}}$ \\
\hline $\mathrm{ML} / \mathrm{M} \cdot \mathrm{L}$ & 39.01 & 35.54 & 33.28 & 25.00 \\
\hline
\end{tabular}

$\mu=0,100 \mathrm{M}, T^{\mathrm{a}}=25^{\circ} \mathrm{C}$

${ }^{a}$ Ma and Martell (1993)

b Bannochie and Martell (1989)

c Smith and Martell (1989)
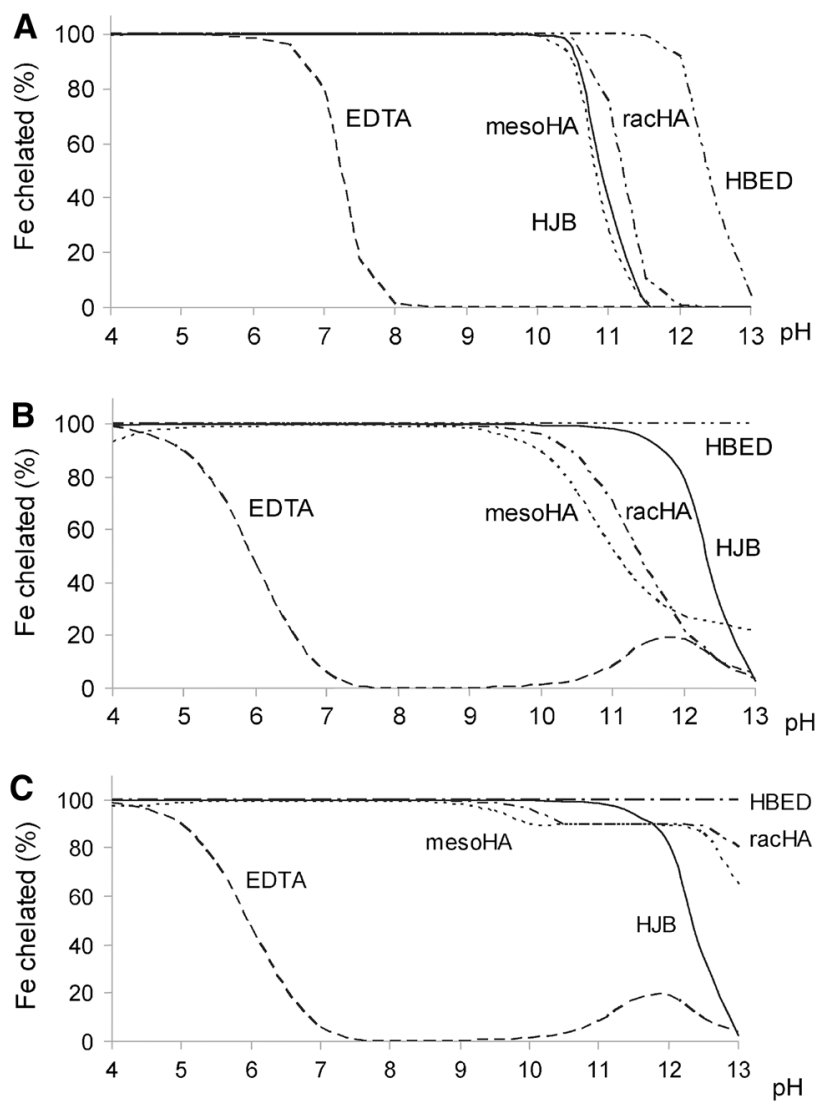

Fig. 1 Percentage of chelated Fe(III) in the presence of HJB $\left(N, N^{\prime}-\right.$ bis(2-hydroxy-5-methylphenyl) ethylenediamine- $N, N^{\prime}$-diacetic acid), HBED ( $N, N$-bis (2-hydroxybenzyl) ethylenediamine- $N, N$-diacetic acid), meso $o, o$-EDDHA (meso-(ethylenediaminedi( $o$-hydroxyphenylacetic acid), rac $o, o$-EDDHA (rac-(ethylenediaminedi( $o$-hydroxyphenylacetic acid), and EDTA-chelating agents in a nutrient solution, soil conditions with $\mathbf{b}$ unlimited $\mathrm{Cu}^{2+}$ and $\mathbf{c}$ limited (normal) $\mathrm{Cu}^{2+}$. Reprinted (adapted) with permission from López-Rayo et al. (2009). Copyright (2009) American Chemical Society

Fe(III)-HBED (Table 1) and its consequent instability in calcareous/alkaline conditions (Fig. 1). In such conditions, $\mathrm{Fe}$ is displaced from the chelate by the high $\mathrm{Ca}^{2+}$ or hydroxyl concentration in the nutrient/soil solution and 

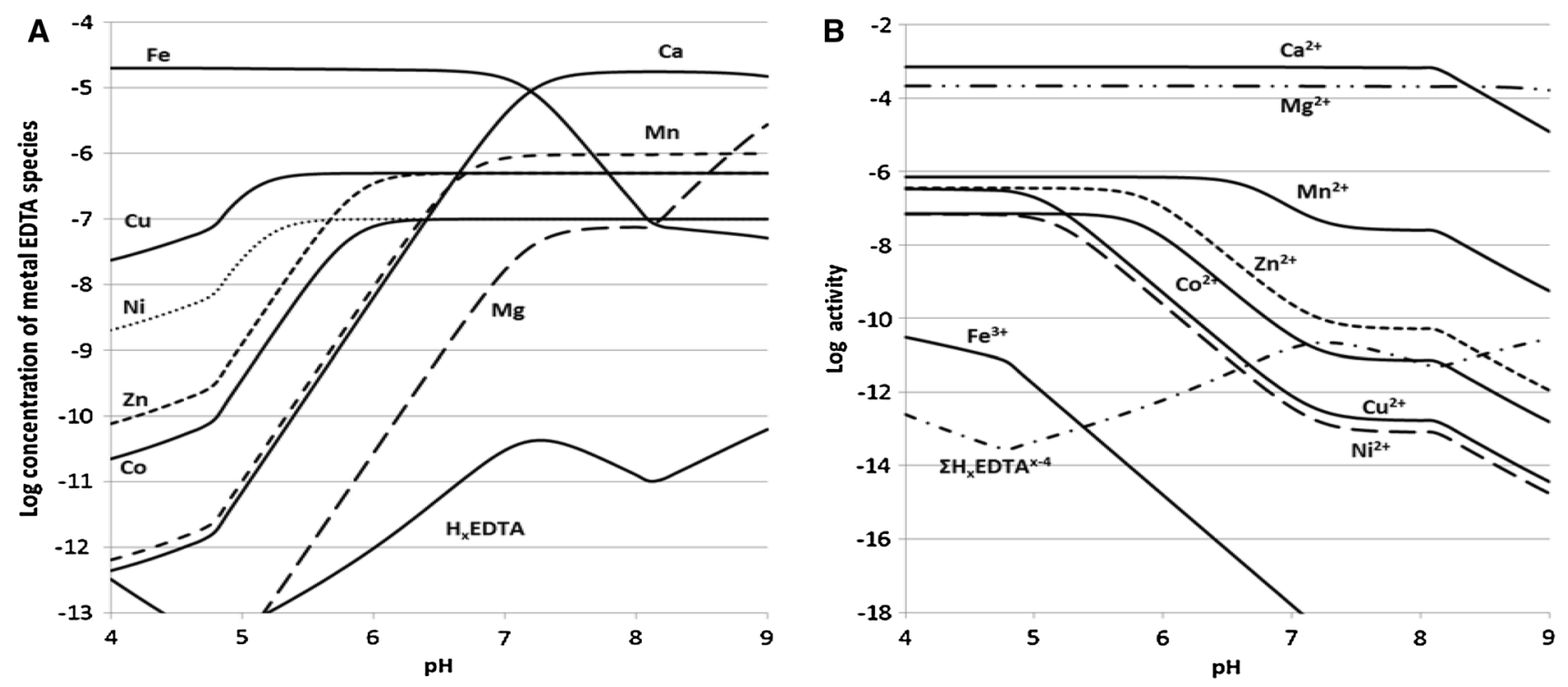

Fig. 2 Concentrations of a EDTA chelate species of indicated cations, and $\mathbf{b}$ free-metal ions and free-ligand species as a function of pH in nutrient solution with $20-\mu \mathrm{M}$ Fe

then, co-precipitates onto the amorphous silica particles or precipitates as iron silicates or oxides. If a highly stable $\mathrm{Fe}$ chelates such as $\mathrm{Fe}(\mathrm{III})-\mathrm{HBED}$ or Fe(III)-EDDHA (ethylenediaminedi( $o$-hydroxyphenylacetic acid), stable until $\mathrm{pH}$ 12 (Fig. 2), is used, Fe precipitation in the growth media or at root surfaces were not expected and the $\mathrm{Si}$ effect on internal plant mechanisms could be studied. The Fe supply with less stable compounds will conduct to chlorosis symptoms before the $\mathrm{Fe}$ elimination from the nutrient solution, especially in hydroponics and does not allow clarifying the internal effect of Si on iron nutrition, if any.

For cucumber plants, several short experiments in hydroponics were compiled in the recent literature (Pavlovic et al. 2013; Gonzalo et al. 2013; Bityutskii et al. 2014), but the described experimental conditions differ greatly among studies. Pavlovic et al. (2013) and Bityutskii et al. (2014) tested two Si doses (0 and $1.5 \mathrm{mM}$ ), and $\mathrm{Fe}$ was supplied as Fe(III)-EDTA when added. The $\mathrm{pH}$ of nutrient solutions was 6.0. In another study (Gonzalo et al. 2013), soybean and cucumber seedlings were grown with $\mathrm{Fe}(\mathrm{III})-$ HBED as Fe source and three different $\mathrm{Si}$ doses (0.0, 0.5 and $1.0 \mathrm{mM}$ ), with a nutrient solution $\mathrm{pH}$ of $7.0-7.5$ and $\mathrm{CaCO}_{3}$ added to each pot to simulate the calcareous soil conditions. In both experimental conditions, total $\mathrm{Fe}$ plant content was not significantly increased by the addition of $\mathrm{Si}$, either when Si was only added before the iron deficiency period or through the entire experiment (Gonzalo et al. 2013; Pavlovic et al. 2013). Silicon supply increased cucumber shoot and root biomass, chlorophyll content and Fe leaf concentration in Fe-deficient plants during 7 or 14 days of Fe deficiency (Pavlovic et al. 2013; Bityutskii et al. 2014), but these effects were not shown after 21 days
(Gonzalo et al. 2013). Therefore, probably the internal effect of Si on Fe nutrition was not focused on the uptake process, but in the internal distribution of the metal inside the plant as proposed by Fu et al. (2012). In any case, further research is needed to corroborate this statement, not only at early growth stages in hydroponics, but in the field and for different plant species. High accumulation of $\mathrm{Fe}$ in roots was observed when plants were treated with Si (Pavlovic et al. 2013; Gonzalo et al. 2013; Bityutskii et al. 2014), attributed to a high amount of $\mathrm{Fe}$ in the root apoplastic pools (Pavlovic et al. 2013) or to its precipitation at root surfaces. As mentioned before, the amount of precipitated $\mathrm{Fe}$ outside roots should be related to the Fe source used. As Gonzalo et al. (2013) used a high-stability $\mathrm{Fe}$ chelate [Fe(III)HBED], the precipitation on root surface in this experiment should be discarded, and it can be concluded that $\mathrm{Fe}$ is stored inside root. When low-stability Fe sources are used, probably both iron root depositions and apoplastic pools will be formed. In any case, the Fe stored in these pools decreases dramatically after the first day of Fe deficiency until their disappearance at the 5th day of the experiment, which was coupled with a $\mathrm{Fe}$ concentration increased in the xylem sap when Si was added (Pavlovic et al. 2013). The extinction of the apoplastic pools could explain the deficiency symptoms that clearly appeared after 21 days of $\mathrm{Fe}$ deprivation. Even though 21 days after the Fe deficiency imposition, the $\mathrm{Fe}$ content in stems was higher in the $\mathrm{Si}$ treated plants (around $24 \%$ of the total $\mathrm{Fe}$ in the plants were located in stems), in comparison with the Si-untreated ones (14\%) (Gonzalo et al. 2013).

For soybean, $\mathrm{Si}$ addition delayed the chlorophyll degradation even after 21 days from $\mathrm{Fe}$ elimination from 
solution and also delayed the plant growth decrease due to iron deficiency. It has been reported that $\mathrm{Si}$ delays chlorophyll degradation in different plant species and under different abiotic stresses (Al-aghabary et al. 2004; Feng et al. 2010; Gottardi et al. 2012) and two possible mechanisms have been mentioned. The first one was related with the $\mathrm{Si}$ structural protection of the chloroplast membranes (Al-aghabary et al. 2004; Feng et al. 2010), and the second with the effect of Si on strengthened cell walls which might contribute to a more favorable position of leaves to intercept light and increase the photosynthesis rate (Ma and Takahasi 2002; Liang 1998). Also, Si could contribute to avoid chlorophyll degradation by the activation of several enzymatic systems (Gottardi et al. 2012; Bybordi 2012). Another hypothesis is that $\mathrm{Si}$ probably contributes to maintain other micronutrients balance, such as $\mathrm{Fe} / \mathrm{Mn}$ ratio (Pich et al. 1994), which is also beneficial in enhancing chlorophyll synthesis, and provides a possible explanation for the stimulation in growth of Fe-deficient plants supplied with Si (Gonzalo et al. 2013; Pavlovic et al. 2013; Bityutskii et al. 2014). Even though the Fe content in leaves was similar for the Si-treated and -untreated plants after 21 days of Fe shortage (Gonzalo et al. 2013). The chlorophyll protection effect has been observed for the soybean seedlings after 21 days of Fe deficiency, but no for cucumber ones. This fact could be explained by a positive correlation observed between the $\mathrm{Fe}$ and $\mathrm{Si}$ content in soybean leaves, but not in cucumber. A Si speciation study might be interesting to determine the role of each silicon form on each metabolic process described above.

The Si-protective effect in the amelioration of Fe chlorosis was more evident for soybean than for cucumber after a long period of deficiency (Gonzalo et al. 2013). Thus, Si influence on iron deficiency might depend on the plant species treated. Pavlovic et al. (2013) concluded that for cucumber, the root responses to Fe deficiency (e.g., root morphological changes, reductive Fe uptake) were indirectly influenced by $\mathrm{Si}$ as a consequence of the improved Fe status in the whole plant, rather than directly caused by Si-modulated expression of strategy I-responsive genes (FRO2, IRT1 and HA1). Nevertheless, the mechanism that explains the role of $\mathrm{Si}$ in Fe transport from root to shoot is still unclear. These differences are probably related to: (a) the different plant strategies developed under Fe deficiency, or (b) differences on $\mathrm{Si}-\mathrm{Fe}$ compounds transport inside plant. Silicon accumulation in cucumber leaves and stems was, respectively, two and three times higher than in soybean (Gonzalo et al. 2013). The process that controls this accumulation was supposed to depend on plant transpiration rates, giving a positive correlation between the $\mathrm{Si}$ content in plants and the transpiration rates. If Fe interacts with $\mathrm{Si}$ in the apoplast and forms the apoplastic deposits already mentioned, $\mathrm{Fe}$ might follow the $\mathrm{Si}$ movement inside the plant and might be effectively remobilize from source to sink. For both species, the highest Si content was found in leaves (around $90 \%$ of the total $\mathrm{Si}$ in the plant) (Gonzalo et al. 2013). In the case of soybean, this $\mathrm{Si}$ content resembled the leaves' Fe content, so it could imply a direct relationship between the $\mathrm{Fe}$ remobilization and transport from root to shoots and the $\mathrm{Si}$ content under $\mathrm{Fe}$ deficiency, which could improve the chlorosis resistance of the plant. Cucumber is considered as a $\mathrm{Si}$ accumulator among other dicots species, therefore the $\mathrm{Si}$ content in leaves was much higher than $\mathrm{Fe}$ content, and no positive correlation was found between them.

Another proposed mechanism involves the enhancement of citrate in plants treated with Si. Citrate is one of the molecules that joined $\mathrm{Fe}$ on its transport through the xylem (Rellán-Alvarez et al. 2010). The increase in citrate concentration in leaf and root tissues and in the xylem sap of Si-treated cucumber plants, especially the first day after $\mathrm{Fe}$ elimination from the nutrient solution (Pavlovic et al. 2013; Bityutskii et al. 2014), should facilitate long-distance transport and $\mathrm{Fe}$ utilization in leaves. However, a high citrate concentration has been shown to inhibit Fe(III) citrate reduction in leaves (Nikolic and Römheld 1999).

Other hypothesis has been tested in cucumber, as the $\mathrm{Si}$ influences on $\mathrm{Fe}$ chelate reductase and the expression profile of the strategy I-related genes FRO2, IRT1 and HA1. After an initial increase, due to the Fe suppression form nutrient solution, their activity gradually decreased and at the end of the experiment it was almost three-fold lower in the plants receiving $\mathrm{Si}$ as compared to those grown without Si (Pavlovic et al. 2013).

In summary, $\mathrm{Si}$ effect on iron plant nutrition under deficiency stress conditions clearly depends on the plant species tested possibly due to the great differences observed in the Si accumulation pattern among species and mechanisms developed to overcome metal deficiency situations.

\section{Zinc deficiency}

In many parts of the world, $\mathrm{Zn}$ deficiency is an important cause of nutritional disorders in plants. Normally, this problem is not related with a low $\mathrm{Zn}$ content in the soil, but with soil characteristics that control the plant availability of this element. In that way, in calcareous soils, like in the case of $\mathrm{Fe}$, the alkaline $\mathrm{pH}$ and the $\mathrm{CaCO}_{3}$ presence decrease the $\mathrm{Zn}^{2+}$ concentration in the soil solution to a limit that will hold plant malnutrition. Other soil characteristics as a low level of organic matter, which can form complexes with the metal that facilitates its plant uptake are also related with the low Zn phytoavailability (Marschner 1995). In general, at $\mathrm{Zn}$ shoot concentrations below, a $15-20 \mathrm{mg} \mathrm{Zn} \mathrm{kg}{ }^{-1}$ dry weight plants begin to show 
deficiency symptoms, such as a decrease in biomass and in the floral fertility, chlorosis and senescence of old leaves and increase in shoot branching (Marschner 1995). Zinc deficiency leads to increased production of reactive oxygen species resulting from lowered $\mathrm{Cu} / \mathrm{Zn}$ superoxide dismutase (CuZn-SOD) activity, the inhibition of protein synthesis and increased Fe accumulation. This causes damage to membranes, membrane proteins, chlorophyll and enzymes, resulting in leaf chlorosis and the inhibition of photosynthesis and growth (Cakmak 2000). Similarly to $\mathrm{Fe}(\mathrm{III})$, which has even lower solubility, Zn solubility in the rhizosphere should be controlled through growth media acidification and low-molecular-weight chelating agents excretion by roots (Sinclair and Krämer 2012; von Wiren et al. 1996). However, some authors consider that the enhancement of $\mathrm{Zn}$ soil availability induced by root changes not seem to play a key role in $\mathrm{Zn}$ efficiency mechanism and that $\mathrm{Zn}$-efficient genotypes utilize $\mathrm{Zn}$ more efficiently through enzymes such as $\mathrm{Cu} / \mathrm{ZnSOD}$ and carbonic anhydrase (Hacisalihoglu and Kochian 2003).

Inside the xylem, $\mathrm{Zn}$ flux into the shoot is mass-flow driven. There is some evidence for the chelation of $\mathrm{Zn}$ by low-molecular-weight ligands inside the xylem. Also, a mass flow-driven transport in the phloem has been described (Erenoglu et al. 2010). Due to the high concentrations of metal-binding compounds and the higher $\mathrm{pH}$ inside the phloem, the chelation of $\mathrm{Zn}$ is particularly important for long-distance transport inside the phloem. Evidences suggest that low-molecular-weight metal chelators might be important ligands for $\mathrm{Zn}$ in plants. Nicotianamine (NA), a non-proteinogenic amino acid acting as high-affinity metal chelator first proposed to act in $\mathrm{Fe}$ and $\mathrm{Cu}$ homeostasis, appears to also have a central role in $\mathrm{Zn}$ homeostasis of plants (Sinclair and Krämer 2012), ensuring symplastic cell-to-cell and phloem mobility of Zn. Further compounds that have been proposed to bind $\mathrm{Zn}$ in plants are organic acids, in particular malate and citrate (Sinclair and Krämer 2012). Cell vacuoles are the major site for storage and detoxification of excess $\mathrm{Zn}$ and a source for $\mathrm{Zn}$ remobilization in periods of deficiency. In the vacuoles of shoot tissues, where organic acid concentrations can reach very high levels, metals are thought to be stored in the form of organic acid complexes (Sinclair and Krämer 2012).

There are several evidences that $\mathrm{Zn}$ distribution in plant changed by the $\mathrm{Si}$ addition in hydroponic and soil experiments (Gu et al. 2011, 2012; Bityutskii et al. 2014) and that both elements presented a similar location in plants $(\mathrm{Gu}$ et al. 2012). Gu et al. (2012) overcome the Si effect due to the metal precipitation in the growth media and try to elucidate the internal role of $\mathrm{Si}$ under $\mathrm{Zn}$ toxicity conditions by maintaining a similar activity of free $\mathrm{Zn}^{2+}$ in solution calculated by the Visual MINTEQ program to be the same for all the Si treatments. In such conditions, a different $\mathrm{Zn}$ distribution pattern was observed in Si-treated plants with a higher metal concentration in roots either in hydroponic or in soil experiments (Gu et al. 2011, 2012; Song et al. 2011). Several explanations were given: (a) Si addition contributes to the root cell wall strengthen delaying the $\mathrm{Zn}^{2+}$ transport to the shoots (Currie and Perry 2007; Gong et al. 2006; Huang et al. 2009; Peleg et al. 2010). Silicon and zinc were mainly located around the root endodermis (Gu et al. 2011), precipitated as $\mathrm{Zn}$ silicates, which may partially inhibit $\mathrm{Zn}$ xylem loading and transport (da Cunha and do Nascimento 2009); this precipitate suffered a slow degradation to $\mathrm{SiO}_{2}$ and then, $\mathrm{Zn}$ was accumulated in vacuoles in an unknown form (Neumann and zur Nieden 2001); (b) silicate precipitation on the plant cell wall (Currie and Perry 2007) increased the $\mathrm{Zn}^{2+}$-binding sites, which may enhance $\mathrm{Zn}^{2+}$ adsorption on the silicate deposits (Wang et al. 2000). That implies a detoxifying action avoiding the metal transport to more sensitive organs inside the plant (da Cunha and do Nascimento 2009; Hodson and Sangster 1999; Shi et al. 2005b). A joint location of $\mathrm{Zn}$ and Si was not only observed in roots, but also in shoots. By using a fractionation technique, it has been shown that the cell wall bound fraction of $\mathrm{Zn}$ in roots, stems, sheaths and leaves of rice seedlings increased after Si addition ( $\mathrm{Gu}$ et al. 2012). Likewise, in Minuartia verna, a Si-accumulator dicotyledonous, Zn silicates were detected in the leaf epidermal cell wall, which explains its Zn tolerance (Neumann et al. 1997). The similar location of $\mathrm{Si}$ and $\mathrm{Zn}$ could be explained by the similar xylem transport mechanism, related with the transpiration rate. Moreover, in iron plaque, $\mathrm{Zn}$ could be adsorbed (Chen et al. $1980 \mathrm{a}, \mathrm{b})$ and remobilized when needed.

Root $\mathrm{Zn}$ deposits could be used under $\mathrm{Zn}$-deficient conditions through the activation of the Zn-deficiency mechanism, but the relationship between Si addition and the content of $\mathrm{Zn}$ chelators responsible of metal distribution inside the plant has not been yet studied. The enhancement of citrate in plants treated with $\mathrm{Si}$ has been described under Fe deficiency (Pavlovic et al. 2013; Bityutskii et al. 2014), this citrate could also play an important role on $\mathrm{Zn}$ distribution in plant. As for $\mathrm{Fe}$, the $\mathrm{Zn}$ pools in the roots could be more mobile under deficiency conditions when $\mathrm{Si}$ was added to the plant, contributing to a better distribution of it, which may help to ameliorate the $\mathrm{Zn}$ deficiency symptoms. As $\mathrm{Si}$ and $\mathrm{Zn}$ accumulations were also detected in leaves, the remobilization of the nutrient via phloem could also contribute to a higher seed and fruit $\mathrm{Zn}$ content, which implies a more efficient use of the available $\mathrm{Zn}$, especially under $\mathrm{Zn}$ shortage. Recently, the effect of $\mathrm{Si}$ on $\mathrm{Zn}$ deficiency has been studied by growing cucumber seedlings without $\mathrm{Zn}$ and two $\mathrm{Si}$ doses (0 and $1.5 \mathrm{mM}$ ) for 2 weeks in hydroponic culture (Bityutskii et al. 2014). Nutrient solution $\mathrm{pH}$ was 6.0. No significant changes were observed in roots or leaves' $\mathrm{Zn}$ and 
chlorophyll concentration due to $\mathrm{Si}$ addition, but $\mathrm{Si}$ partially diminished leaves necrotic spots probably due to its indirect effect by enhancing antioxidant defense capacity in plant tissues. Root citrate concentration increased by $\mathrm{Si}$ supply in Zn-deficient plants was fourfold lower than in the $\mathrm{Si}$-treated Fe-deficient ones and the mechanism of reutilization of root apoplastic $\mathrm{Fe}$ via phenolics induced by $\mathrm{Si}$ nutrition did not appear under $\mathrm{Zn}$ deficiency. Authors concluded that there were no evidences of Si alleviation of $\mathrm{Zn}$-deficiency symptoms, but as plants were grown without $\mathrm{Zn}$ in the nutrient solution, the possibility of $\mathrm{Zn}$ pools formation was suppressed, therefore their remobilization was not possible. In a preliminary hydroponic experiment done by our group with soybean at calcareous $\mathrm{pH}$ (unpublished), a higher $\mathrm{Zn}$ content in Si-treated plant leaves and a clear improvement of SPAD index in comparison with the non-treated ones were shown. In that study, plants were previously grown in a complete nutrient solution for 2 weeks before the $\mathrm{Zn}$ elimination. These results resemble the $\mathrm{Si}$ effect on Fe deficiency, and clearly further research is required to confirm this hypothesis.

Two $\mathrm{Zn}$ sources are mainly used in nutrient solution or are added to soils as fertilizers, $\mathrm{ZnSO}_{4}$ and $\mathrm{Zn}$-EDTA. $\mathrm{Zn}$ EDTA stability constant is 17.5 , which is much higher than that of Ca-EDTA (11.6) (Norvell 1991) (Fig. 2). Therefore, little chelated $\mathrm{Zn}$ is substituted by $\mathrm{Ca}$ in neutral and calcareous soils and $\mathrm{Zn}$-EDTA remains effective in such soils (Fig. 2). At calcareous $\mathrm{pH}$, soluble $\mathrm{ZnSO}_{4}$ tends to precipitate as $\mathrm{Zn}(\mathrm{OH})_{2}$, and become not available for plant nutrition, therefore this product is not recommended as $\mathrm{Zn}$ source on deficiency assays.

\section{Copper deficiency}

Copper concentrations in soils range between 3 and $100 \mathrm{mg} /$ $\mathrm{kg}$, but only about $1-20 \%$ exists as free, readily bioavailable $\mathrm{Cu}^{2+}$, the majority is bound to organic matter. Copper is fairly immobile between cell tissues, and deficiency symptoms first appear in the newly formed, younger cells and the reproductive parts. Symptoms of deficiency include impaired photosynthetic electron transport, reduced respiration, and stunted growth due to defects in apical meristems as well as rolling-up and wilting of leaves (Marschner 1995).

There are fewer studies that review the $\mathrm{Si}-\mathrm{Cu}$ interaction in plants (Nowakowski and Nowakowska 1997; Li et al. 2008; Khandekar and Leisner 2011; Frantz et al. 2011). In Arabidopsis thaliana, $\mathrm{Cu}$ toxicity symptoms such as chlorosis on leaves and reduction of shoot and root biomass, were diminished by a Si addition to the nutrient solution ( $\mathrm{Li}$ et al. 2008; Khandekar and Leisner 2011), similar findings were observed for wheat (Nowakowski and Nowakowska 1997). But leaf $\mathrm{Cu}$ concentration was not significantly changed as a result of $\mathrm{Si}$ addition, suggesting that $\mathrm{Si}$ influenced the distribution or bioavailability of $\mathrm{Cu}$ within leaves under $\mathrm{Cu}$ stress (Li et al. 2008). The formation of Si deposits on the cell wall that increased the $\mathrm{Cu}$-binding sites and avoided the impact of such high $\mathrm{Cu}$ doses on plant cells that had been proposed to explain this fact, similar to those proposed for other micronutrients toxicity (Ma and Yamaji 2006; Wang et al. 2000; Rogalla and Römheld 2002; Liang et al. 2007; Frantz et al. 2011). But this could not be the sole mechanism to explain the $\mathrm{Si}$-treated plant behavior against $\mathrm{Cu}$ toxicity, because high levels of molecules that bind $\mathrm{Cu}$, as a strategy to minimize its toxic effect, were maintained or even increased when $\mathrm{Si}$ was added, therefore more than one response should be activated to tolerate $\mathrm{Cu}$ toxicity (Khandekar and Leisner 2011). The response to $\mathrm{Cu}$ toxicity of two ornamental plant species, a Si accumulator zinnia and a Si non-accumulator snapdragon, with and without supplemental $\mathrm{Si}$ grown in hydroponics was also studied (Frantz et al. 2011). Si doses were $0.1,1.7$ and $3.4 \mathrm{mM}$, and $\mathrm{Cu}$ concentrations ranging between 1.5 and $150 \mu \mathrm{M} \mathrm{Cu}$, at $\mathrm{pH}$ 5.7. Enzymatic assays and elemental analysis of leaves, stems, and roots revealed that both species responded to $\mathrm{Si}$ addition, although there appears to be differences in the extent of Si-mediated amelioration of $\mathrm{Cu}$ toxicity. Authors proposed that $\mathrm{Si}$ helps generate additional apoplastic $\mathrm{Cu}$-binding sites, sequestering the metal and thereby reducing its toxic effects. In the case of these two plants, Si-accumulating zinnia is more effective at using $\mathrm{Si}$, perhaps by generating stress despite tissue concentrations remaining high (Samuels et al. 1991). This strongly indicates that a soluble fraction of $\mathrm{Si}$ is necessary to elicit Si-induced resistance, and because $\mathrm{Si}$ is so poorly soluble, a steady, consistent supply is necessary to derive maximum benefit. It is also possible that snapdragon uses additional mechanisms to alleviate $\mathrm{Cu}$ stress and perhaps only activates $\mathrm{Si}$-mediated processes once a particular threshold is exceeded (Frantz et al. 2011). Support for this hypothesis comes from the observation that a much higher level of $\mathrm{Cu}$ was needed to elicit a detrimental response in snapdragon as compared with zinnia. It could also be proposed that $\mathrm{Si}$ accumulators already possess the necessary machinery to take advantage of $\mathrm{Si}$, whereas $\mathrm{Si}$ non-accumulators lack some or all of the extensive genetic or enzymatic machinery for such responses (Frantz et al. 2011).

No references are available about the effect of Si supply on $\mathrm{Cu}$ deficiency, but the $\mathrm{Cu}$-binding sites in the apoplast or cell wall promoted by Si supply and its incidence on some oxidative mechanisms also induced by $\mathrm{Cu}$ deficiency may encourage a further research on this subject.

\section{Manganese deficiency}

Plant species and cultivars within species differ considerably in susceptibility to Mn deficiency. For example, oat, wheat, soybean or peaches are very susceptible, whereas 
maize and rye are much less susceptible (Reuter et al. 1988). In cereals, such as barley and wheat, Mn deficiency leads to significant yield reductions and may cause complete loss of crops during the winter. Below the critical deficiency level, dry matter production, net photosynthesis and chlorophyll content decline rapidly, due to the effect of Mn deficiency on thylakoid structure and chlorophyll degradation (Papadakis et al. 2007), leading to the development of characteristic interveinal leaf chlorosis, whereas rates of respiration and transpiration remain unaffected. In dicotyledonous plants, interveinal chlorosis of the younger leaves is the most distinct symptom of Mn deficiency, whereas in cereals, greenish gray spots on the more basal leaves (gray speck) are the major visual symptoms. Soils known to cause Mn deficiency are typically sandy and calcareous, which in combination with a high content of soil organic matter favors oxidation of soluble $\mathrm{Mn}^{2+}$ to plant unavailable $\mathrm{MnO}_{2}$ (Husted et al. 2005).

Manganese and Si interaction in different plants such as rice (Okuda and Takahashi 1962), barley (Williams and Vlamis 1957; Horiguchi and Morita 1987), bean (Horst and Marschner 1987), and pumpkin (Iwasaki and Matsumura 1999) grown in hydroponics has been described. Generally, $\mathrm{MnSO}_{4}$ is used as $\mathrm{Mn}$ source in nutrient solution or added as fertilizer in the soil, but the well-aerated conditions that characterize growth media favor the formation of oxidized Mn species-Mn(III) and Mn(IV) (Lindsay 1979), so that precipitation of insoluble minerals might decrease $\mathrm{Mn}$ solubility further, to a very low concentrations. Thermodynamically, oxidation of $\mathrm{Mn}^{2+}$ to $\mathrm{Mn}^{4+}$ is favored in aerated soils above $\mathrm{pH} 4$, but the high activation energy required for $\mathrm{Mn}^{2+}$ oxidation inhibits or postpones oxidation processes (Gilkes and McKenzie 1988). These facts will promote the deposition of Mn oxides on root surfaces, independently of $\mathrm{Si}$ addition to the media. Moreover, in rice, $\mathrm{Si}$ contributes to enhance the roots oxidizing capacity giving a higher Mn-oxidation rate in the rhizosphere and increasing the precipitation outside the plant (Okuda and Takahashi 1962). As mentioned before for Fe and Zn, these deposits could be used under Mn deficiency, and could ameliorate for a while Mn-deficiency symptoms. In barley, cucumber and bean (Williams and Vlamis 1957; Horiguchi and Morita 1987; Horst and Marschner 1987; Shi et al. 2005a), Si contributed to a Mn homogeneous distribution in the leaf instead of its concentration in necrotic spots, but the mechanism that controls this is still unknown. On the contrary, Mn absorption by pumpkin was not affected by $\mathrm{Si}$ addition, but promoted a Mn accumulation on the trichomes base (Iwasaki and Matsumura 1999). In cowpea, a lower amount of $\mathrm{Mn}$ in the apoplast was obtained when $\mathrm{Si}$ was added to the media. This could be explained through the metal adsorption on cell walls mediated by the $\mathrm{Si}$ deposits as for Zn (Horst et al. 1999), but also because soluble $\mathrm{Si}$ in the apoplast may affect Mn-oxidation state promoting its precipitation (Iwasaki et al. 2002). Cucumber plants treated with Si presented more than $90 \%$ of the Mn bound to the cell wall, in comparison with untreated plants, in which $50 \%$ of the Mn was in the symplast and $50 \%$ in the apoplast (Rogalla and Römheld 2002; Wiese et al. 2007). Recently, it has been concluded that the Si supply to the nutrient solution did not seem to improve Mn-deficiency symptoms of cucumber (Bityutskii et al. 2014), but as mentioned above for $\mathrm{Zn}$, plants were grown with any $\mathrm{Mn}$ in the nutrient solution, therefore the possibility of pools formation was eliminated. Either $\mathrm{Mn}$ is present as a precipitate in the apoplast or bound to cell walls, plants might use it in case of deficiency, although the amount of $\mathrm{Mn}$ might not be enough to completely suppressed symptoms. Also the mechanism that controls this mobilization, the location of Mn deposits, the Mn availability from deposits and the Mn speciation on them requires further research and the utilization of sophisticated image techniques.

The beneficial effect of $\mathrm{Si}$ in cucumber was also explained by its contribution to decrease the membrane lipid peroxidation through the increment of different antioxidants (Shi et al. 2005a). Dragišic et al. (2007) concluded that $\mathrm{Si}$ contributes indirectly to a decrease in $\cdot \mathrm{OH}$ in the leaf apoplast by decreasing the free apoplastic $\mathrm{Mn}^{2+}$, thus regulating the Fenton reaction, and protect plant against Mn toxicity. This mechanism could also explain the plant protection against deficiency.

\section{Perspectives}

Silicon influence on Fe deficiency is mainly a consequence of the improvement of $\mathrm{Fe}$ distribution in the plant, as no increase on Fe uptake has been described after Si addition. Iron storage in roots (apoplastic or plaque) pools seems to be favored by $\mathrm{Si}$ addition, and its remobilization seems to be the main factor of the beneficial effect of $\mathrm{Si}$ on Fe deficiency. In respect to the rest of micronutrients, metal root deposits similar to those of Fe are reported in the literature under toxicity, but it is necessary to test their presence under normal growth conditions. Recently, the distributions of $\mathrm{Si}$, $\mathrm{Fe}, \mathrm{Zn}, \mathrm{Mn}$ and $\mathrm{Cu}$ were mapped in the node, internode and leaf sheath of rice (Oryza sativa) cultured with $\mathrm{Si}$ in hydroponics, using synchrotron X-ray fluorescence (S$\mathrm{XRF}$ ) and high-resolution secondary ion mass spectrometry (NanoSIMS) (Moore et al. 2014). Silicon generally showed cell wall localization and no $\mathrm{Si}$ is detected in the vacuoles, probably because of the lack of Si transporters located in the tonoplast (Moore et al. 2014). Moreover, Si was found to accumulate in oval granules, likely to be the starch grains, in the cytoplasm of the fundamental parenchyma of the internode (Moore et al. 2014). Within the node, Zn was 
localized in the vacuoles of the parenchyma cell bridge bordering the enlarged and diffused vascular bundles, whereas $\mathrm{Fe}$ and $\mathrm{Mn}$ were localized in the fundamental parenchyma cells, with Fe being strongly co-localized with phosphorus in the vacuoles. The formation of insoluble $\mathrm{Fe}-$ $\mathrm{P}$ complexes in the vacuoles explains the relatively low mobility of Fe in plants (Marschner 2012). Copper shows a very different distribution pattern from that of the other transition metals with a strong localization to various types of vascular bundles mainly in the cell walls (Moore et al. 2014). A similar study about roots will contribute to explain the Si role on metal accumulation at non-toxic concentrations and the possibilities of the accumulated metal to be transported to the shoot or not. Moreover, the effect of $\mathrm{Si}$ addition on the accompanying metal molecules (i.e., citrate) that are involved in long-distance transport in plants also requires attention. Nevertheless, new methods and methodologies are neccessary to cope with further investigations on this topic, such as S-XRF or NanoSIMS, which combined with the traditional analysis will contribute to elucidate the Si role on micronutrient deficiency.

Acknowledgments Author would like to thank Dr. Matichenkov and Dr. Lucena for the facilities given to research in this topic. Also to Dr. Lucena for his help in Fig. 2 design and the financial support of the MINECO project AGL2010-18048.

\section{References}

Adatia MH, Besford RT (1986) The effects of silicon on cucumber plants grown in recirculating nutrient solution. Ann Bot 58:343-511

Al-aghabary K, Zhu Z, Shi Q (2004) Influence of silicon supply on chlorophyll content, chlorophyll fluorescence, and antioxidative enzyme activities in tomato plants under salt stress. J Plant Nutr 27:2101-2115

Bannochie CJ, Martell AE (1989) Affinities of racemic and meso forms of $N, N^{\prime}$-ethylenebis [2-(o-hydroxyphenyl) glycine] for divalent and trivalent metal ions. J Am Chem Soc 111(13):4735-4742

Baxter IR, Vitek O, Lahner B, Muthukumar B, Borghi M, Morrissey J, Guerinot ML, Salt DE (2008) The leaf ionome as a multivariable system to detect plant's physiological status. Proc Natl Acad Sci USA 105:12081-12086

Bienfait HF, Vandenbriel W, Meslandmul NT (1985) Free space iron pools in roots generation and mobilization. Plant Physiol 78:596-600

Birchall JD (1990) Role of silicon in biology. Chem $\mathrm{Br}$ 26(2):141-144

Bityutskii N, Pavlovic J, Yakkonen K, Maksimovi V, Nikolic M (2014) Contrasting effect of silicon on iron, zinc and manganese status and accumulation of metal mobilizing compounds in micronutrient-deficient cucumber. Plant Physiol Biochem 74:205-211

Briat JF, Fobis-Loisy I, Grignon N, Lobreaux S, Pascal N, Savino G, Thoiron S, von Wiren N, Van Wuytswinkel O (1995) Cellular and molecular aspects of iron metabolism in plants. Biol Cell 84:69-81
Bybordi A (2012) Effect of ascorbic acid and silicium on photosynthesis, antioxidant enzyme activity, and fatty acid contents in canola exposure to salt stress. J Integr Agric 11:1610-1620

Cakmak I (2000) Tansley review No. 111—possible roles of zinc in protecting plant cells from damage by reactive oxygen species. New Phytol 146(2):185-205

Casey WH, Kinrade SD, Knight CTG, Rains DW, Epstein E (2004) Aqueous silicate complexes in wheat Triticum aestivum L. Plant Cell Environ 27(1):51-54

Chen CC, Dixon JB, Turner FT (1980a) Iron coatings on rice roots: mineralogy and quantity influencing factors. Soil Sci Soc Am J 44:635-639

Chen CC, Dixon JB, Turner FT (1980b) Iron coatings on rice roots: morphology and models of development. Soil Sci Soc Am J 44:1113-1119

Chiba Y, Mitani N, Yamaji N, Ma JF (2009) HvLsi1 is a silicon influx transporter in barley. Plant J 57:810-818

Currie HA, Perry CC (2007) Silica in plants: biological, biochemical and chemical studies. Ann Bot 100:1383-1389

da Cunha KPV, do Nascimento CWA (2009) Silicon effects on metal tolerance and structural changes in maize (Zea mays L.) grown on a cadmium and zinc enriched soil. Water Air Soil Pollut 197:323-330

da Cunha KPV, do Nascimento CWA, da Silva AJ (2008) Silicon alleviates the toxicity of cadmium and zinc for maize (Zea mays L.) grown on a contaminated soil. J Plant Nutr Soil Sci 171:849-853

Datnoff LE, Snyder CH, Korndorfer GH (eds) (2001) Silicon in Agriculture. Elsevier, Amsterdam

Dragišić J, Bogdanović J, Maksimović V, Nikolic M (2007) Silicon modulates the metabolism and utilization of phenolic compounds in cucumber (Cucumis sativus L.) grown at excess manganese. J Plant Nutr Soil Sci 170(6):739-744

Emadian SF, Newton RJ (1989) Growth enhancement of loblolly pine (Pinus taeda L.) seedlings by silicon. J Plant Physiol 134:98-103

Epstein E (1999) Silicon. Annu Rev Plant Physiol Plant Mol Biol 50:641-664

Erenoglu EB, Kutman UB, Ceylan Y, Yildiz B, Cakmak I (2010) Improved nitrogen nutrition enhances root uptake, root-to-shoot translocation and remobilization of zinc $\left({ }^{6} \mathrm{Zn}\right)$ in wheat. New Phytol 189(2):438-448

Evans DE (2004) Aerenchyma formation. New Phytol 161(1):35-49

Fauteux F, Remus-Borel W, Menzies JG, Belanger RR (2005) Silicon and plant disease resistance against pathogenic fungi. FEMS Microbiol Lett 249:1-6

Feng J, Shi Q, Wang X, Wei M, Yang F, Xu H (2010) Silicon supplementation ameliorated the inhibition of photosynthesis and nitrate metabolism by cadmium (Cd) toxicity in Cucumis sativus L. Sci Hortic 123:521-530

Frantz JM, Khandekar S, Leisner S (2011) Silicon differentially influences copper toxicity response in silicon-accumulator and non-accumulator species. J Am Soc Hort Sci 136(5):329-338

Fu YQ, Shen H, Wu DM, Cai KZ (2012) Silicon-mediated amelioration of $\mathrm{Fe}^{2+}$ toxicity in rice (Oryza sativa L.) roots. Pedosphere 22(6):795-802

García-Mina JM, Bacaicoa E, Fuentes M, Casanova E (2013) Fine regulation of leaf iron use efficiency and iron root uptake under limited iron bioavailability. Plant Sci 198:39-45

Gilkes RJ, McKenzie RM (1988) Geochemistry and mineralogy of manganese in soils. In: Graham R, Hannan RJ, Uren NC (eds) Manganese in soils and plants. Kluwer Academic Publishers, Dordrecht, pp 23-35

Gong HJ, Randall DP, Flowers TJ (2006) Silicon deposition in the root reduces sodium uptake in rice (Oryza sativa L.) seedlings by reducing bypass flow. Plant, Cell Environ 29:1970-1979 
Gonzalo MJ, Lucena JJ, Hernández-Apaolaza L (2013) Effect of silicon addition on soybean (Glycine max) and cucumber (Cucumis sativus) plants grown under iron deficiency. Plant Physiol Biochem 70:455-461

Gottardi S, Iacuzzo F, Tomasi N, Cortella G, Manzocco L, Pinton R, Römheld V, Mimmo T, Scanpicchio M, Dalla Costa L, Cesco S (2012) Beneficial effects of silicon on hydroponically grown corn salad (Valerianella locusta (L.) Laterr) plants. Plant Physiol Biochem 56:14-23

Gu HH, Qiu H, Tian T, Zhan SS, Deng THB, Chaney RL, Wang SZ, Tang YT, Morel JL, Qiu RL (2011) Mitigation effects of silicon rich amendments on heavy metal accumulation in rice (Oryza sativa L.) planted on multimetal contaminated acidic soil. Chemosphere 83(9):1234-1240

Gu HH, Zhan SS, Wang SZ, Tang YT, Chaney RL, Fang XH, Cai XD, Qiu RL (2012) Silicon-mediated amelioration of zinc toxicity in rice (Oryza sativa L.) seedlings. Plant Soil 350:193-204

Hacisalihoglu G, Kochian LV (2003) How do some plants tolerate low levels of soil zinc? Mechanisms of zinc efficiency in crop plants. New Phytol 159(2):341-350

Hindt MN, Guerinot ML (2012) Getting sense for signals: regulation of the plant iron deficiency response. Biochim Biophys Acta 1823:1521-1530

Hodson MJ, Sangster AG (1999) Aluminium/silicon interactions in conifers. J Inorg Biochem 76:89-98

Horiguchi T, Morita S (1987) Mechanism of manganese toxicity and tolerance of plants. IV. Effect of silicon on alleviation of manganese toxicity of barley. J Plant Nutr 10:2299-2310

Horst WJ, Marschner H (1987) Effect of silicon on manganese tolerance of bean plants (Phaseolus vulgaris L.). Plant Soil 50:287-303

Horst WJ, Fecht M, Naumann A, Wissemeier AH, Maier P (1999) Physiology of manganese toxicity and tolerance in Vigna unguiculata (L.) Walp. J Plant Nutr Soil Sci 162:263-274

Huang CF, Yamaji N, Nishimura M, Tajima S, Ma JF (2009) A rice mutant sensitive to al toxicity is defective in the specification of root outer cell layers. Plant Cell Physiol 50:976-985

Husted S, Thomsen MU, Mattsson M, Schjoerring J (2005) Influence of nitrogen and sulphur form on manganese acquisition by barley (Hordeum vulgare). Plant Soil 268:309-317

Iwasaki K, Matsumura A (1999) Effect of silicon on alleviation of manganese toxicity in pumpkin (Cucurbita moschata Duch cv. Shintosa). Soil Sci Plant Nutr 45:909-920

Iwasaki K, Maier P, Fecht M, Horst WJ (2002) Effect of silicon supply on apoplastic manganese concentrations in leaves and their relation to manganese tolerance in cowpea (Vigna unguiculata (L.) Walp). Plant Soil 238:281-288

Jin CW, You GY, He YF, Tang C, Wu P, Zheng SJ (2007) Iron deficiency-induced secretion of phenolics facilitates the reutilization of root apoplastic iron in red clover. Plant Physiol 144:278-285

Khandekar S, Leisner S (2011) Soluble silicon modulates expression of Arabidopsis thaliana genes involved in copper stress. J Plant Physiol 168:699-705

Li YC, Adva AK, Sumner ME (1989) Response of cotton cultivars to aluminum in solutions with varying silicon concentrations. J Plant Nutr 12:881-892

Li J, Leisner S, Frantz J (2008) Alleviation of copper toxicity in Arabidopsis thaliana by silicon addition to hydroponic solutions. J Am Soc Hort Sci 133(5):670-677

Liang Y (1998) Effects of Si on leaf ultrastructure, chlorophyll content and photosynthetic activity in barley under salt stress. Pedosphere 8:289-296

Liang Y, Si J, Römheld V (2005a) Silicon uptake and transport is an active process in Cucumis sativus. New Phytol 167:797-804
Liang YC, Wong JWC, Wei L (2005b) Silicon-mediated enhancement of cadmium tolerance in maize (Zea mays L.) grown in cadmium contaminated soil. Chemosphere 58:475-483

Liang YC, Sun WC, Zhu YG, Christie P (2007) Mechanisms of silicon-mediated alleviation of abiotic stresses in higher plants: a review. Environ Pollut 47:422-428

Lindsay WL (1979) Chemical equilibria in soils. Wiley, New York

Longnecker N, Welch RM (1990) Accumulation of apoplastic iron in plant roots. Plant Physiol 92:17-22

López-Rayo S, Hernández D, Lucena JJ (2009) Chemical evaluation of $\mathrm{HBED} / \mathrm{Fe}^{3+}$ and the novel $\mathrm{HJB} / \mathrm{Fe}^{3+}$ chelates as fertilizers to alleviate iron choruses. J Agric Food Chem $57: 8504-8513$

Ma JF (2004) Role of silicon in enhancing the resistance of plants to biotic and abiotic stresses. Soil Sci Plant Nutr 50:11-18

Ma R, Martell AE (1993) Protonation constants and metal ion binding constants of $\mathrm{N}, \mathrm{N}$-bis (2-hydroxyphenyl)- $\mathrm{N}, \mathrm{N}$-ethylenediaminediacetic acid. Inorg Chim Acta 209(1):71-78

Ma JF, Takahasi E (2002) Soil, fertilizer, and plant Silicon Research in Japan. Elsevier, Amsterdam

Ma JF, Yamaji N (2006) Silicon uptake and accumulation in higher plants. Trends Plant Sci 11:392-397

Ma JF, Tamai K, Yamaji N, Mitani N, Konishi S, Katsuhara M, Ishiguro M, Murata Y, Yano M (2006) A silicon transporter in rice. Nature 440:688-691

Ma JF, Yamaji N, Mitani N, Tamai K, Konishi S, Fujiwara T, Katsuhara M, Yano M (2007) An efflux transporter of silicon in rice. Nature 448:209-212

Marschner H (1995) Mineral nutrition of higher plants, 3rd edn. Academic Press, London

Marschner P (2012) Marschner's mineral nutrition of higher plants. Academic Press, London

Mitani N, Ma JF (2005) Uptake system of silicon in different plant species. J Exp Bot 56:1255-1261

Mitani N, Ma JF, Iwashita T (2005) Identification of silicon form in the xylem of rice (Oryza sativa L.). Plant Cell Physiol 46(2):279-283

Mitani N, Yamaji N, Ma JF (2009a) Identification of maize silicon influx transporters. Plant Cell Physiol 50:5-12

Mitani N, Chiba Y, Yamaji N, Ma JF (2009b) Identification and characterization of maize and barley Lsi2-like silicon efflux transporters reveals a distinct silicon uptake system from that in rice. Plant Cell 21:2133-2142

Mitani-Ueno N, Ogai H, Yamaji N, Ma JF (2013) Physiological and molecular characterization of $\mathrm{Si}$ uptake in wild rice species. Physiol Plant. doi:10.1111/ppl.12125

Mitsui S, Takatoh H (1963) Nutritional study of silicon in graminaceous crops. Part I. Soil Sci Plant Nutr 9:49-53

Montpetit J, Vivancos J, Mitani-Ueno N, Yamaji N, Remus-Borel W, Belzile F, Ma JF, Belanger RR (2012) Cloning, functional characterization and heterologous expression of TaLsi1, a wheat silicon transporter gene. Plant Mol Biol 79:35-46

Moore KL, Chen Y, van de Meene AML, Hughes L, Liu W, Geraki T, Mosselmans F, McGrath SP, Grovenor C, Zhao FJ (2014) Combined NanoSIMS and synchrotron X-ray fluorescence reveal distinct cellular and subcellular distribution patterns of trace elements in rice tissues. New Phytol 201:104-115

Neumann D, zur Nieden U (2001) Silicon and heavy metal tolerance of higher plants. Phytochem 56:685-692

Neumann D, zur Nieden U, Schwieger W, Leopold I, Lichtenberger O (1997) Heavy metal tolerance of Minuartia verna. J Plant Physiol 151:101-108

Nikolic M, Römheld V (1999) Mechanism of Fe uptake by the leaf symplast: is $\mathrm{Fe}$ inactivation in leaf a cause of Fe deficiency chlorosis? Plant Soil 215:229-237 
Norvell WA (1991) Reactions of metal chelates in soils and nutrient solutions. In: Micronutrients in agriculture. SSSA Book Series 4 Soil Sci Soc Am

Nowakowski W, Nowakowska J (1997) Silicon and copper interaction in the growth of spring wheat seedlings. Biol Plant 39(3):463-466

Okuda A, Takahashi E (1962) Effect of silicon supply on the injuries due to excessive amounts of $\mathrm{Fe}, \mathrm{Mn}, \mathrm{Cu}, \mathrm{As}, \mathrm{AI}, \mathrm{Co}$ of barley and rice plant. Jpn J Soil Sci Plant Nutr 33:1-8

Papadakis IE, Giannakoula A, Therios IN, Bosabalidis AM, Moustakas M, Nastou A (2007) Mn-induced changes in leaf structure and chloroplast ultrastructure of Citrus volkameriana (L.) plants. J Plant Physiol 164:100-103

Pavlovic J, Samardzic J, Maksimovic V, Timotijevic G, Stevic N, Laursen KH, Hansen TH, Husted S, Schjoerring JK, Liang Y, Nikolic M (2013) Silicon alleviates iron deficiency in cucumber by promoting mobilization of iron in the root apoplast. New Phytol 198(4):1096-1107

Peleg Z, Saranga Y, Fahima T, Aharoni A, Elbaum R (2010) Genetic control over silica deposition in wheat awns. Physiol Plantarum 140:10-20

Pich A, Scholz G, Stephan UW (1994) Iron-dependent changes of heavy metals, nicotianamine, and citrate in different plant organs and in xylem exudate of two tomato genotypes. Nicotianamine as possible copper translocator. Plant Soil 165:189-196

Rellán-Alvarez R, Giner-Martínez-Sierra J, Orduna J, Orera I, Rodríguez-Castrillón JA, Garcia-Alonso JI, Abadía J, AlvarezFernandez A (2010) Identification of a tri-iron(III), tri-citrate complex in the xylem sap of iron deficient tomato resupplied with iron: new insights into plant iron long distance transport. Plant Cell Physiol 51:91-102

Reuter DJ, Alston AM, McFarlane JD (1988) Occurrence and correction of manganese deficiency in plants. In: Graham RD et al (eds) Manganese in soils and plants. Kluwer Academic Publication, Dordrecht, pp 205-244

Rogalla H, Römheld V (2002) Role of leaf apoplast in siliconmediated manganese tolerance of Cucumis sativus L. Plant Cell Environ 25:549-555

Römheld V, Marschner H (1986) Mobilization of iron in the rhizosphere of different plant species. In: Tinker B, Laüchli A (eds) Advances in plant nutrition, vol 2. Praeger, New York

Samuels AL, Glass ADM, Menzies JG, Ehret DL (1991) Mobility and deposition of silicon in cucumber plants. Plant Cell Environ 14:485-492

Savant NK, Snyder GH, Datnoff LE (1997) Silicon management and sustainable rice production. Adv Agron 58:151-199

Shi Q, Bao Z, Zhu Z, He Y, Qian Q, Yu J (2005a) Silicon mediated alleviation of $\mathrm{Mn}$ toxicity in Cucumis sativus in relation to activities of superoxide dismutase and ascorbate peroxidase. Phytochemistry 66:1551-1559

Shi X, Zhang C, Wang H, Zhang F (2005b) Effect of Si on the distribution of $\mathrm{Cd}$ in rice seedlings. Plant Soil 272:53-60

Sinclair SA, Krämer U (2012) The zinc homeostasis network of land plants. Biochim Biophys Acta 1823:1553-1567

Smith RM, Martell AE (1989) Critical stability constants, vol 6: Second supplement Plenum Press, New York, pp 173-174

Song AL, Li P, Li ZJ, Fan FL, Nikolic M, Liang YC (2011) The alleviation of zinc toxicity by silicon is related to zinc transport and antioxidative reactions in rice. Plant Soil 344:319-333

Takahashi E, Ma JF, Miyake Y (1990) The possibility of silicon as an essential element for higher plants. Comments Agric Food Chem 2:99-122

von Wiren N, Marschner H, Römheld V (1996) Roots of iron-efficient maize also absorb phytosiderophore-chelated zinc. Plant Physiol 111(4):1119-1125

Wang LJ, Wang YH, Chen Q, Cao WD, Li M, Zhan FS (2000) Silicon induced cadmium tolerance of rice seedlings. J Plant Nutr 23:1397-1406

Waters BM, Uauy C, Dubcovsky J, Grusak MA (2009) Wheat (Triticum aestivum) NAM proteins regulate the translocation of iron, zinc, and nitrogen compounds from vegetative tissues to grain. J Exp Bot 60:4263-4274

Wiese H, Nikolic M, Römheld V (2007) Silicon in plant nutrition. Effect of zinc, manganese and boron leaf concentrations and compartmentation. In: Sattelmacher B, Horst WJ (eds) The apoplast of higher plants: compartment of storage, transport and reactions. Springer, Dordrecht, pp 33-47

Williams DE, Vlamis J (1957) The effect of silicon on yield and manganese-54 uptake and distribution in the leaves of barley grown in culture solutions. Plant Physiol 32:404-409

Wutscher HK (1989) Growth and mineral nutrition of young orange trees grown with high levels of silicon. HortScience 24:275-277

Yamaji N, Ma JF (2009) A transporter at the node responsible for inter-vascular transfer of silicon in rice. Plant Cell 21:2878-2883

Yamaji N, Mitani N, Ma JF (2008) A transporter regulating silicon distribution in rice shoots. Plant Cell 20:1381-1389

Yamaji N, Chiba Y, Mitani-Ueno N, Ma JF (2012) Functional characterization of a silicon transporter gene implicated in silicon distribution in barley. Plant Physiol 160:1491-1497

Zhang X, Zhang F, Mao D (1998) Effect of iron plaque outside roots on nutrient uptake by rice (Oryza sativa L.): zinc uptake by $\mathrm{Fe}-$ deficient rice. Plant Soil 202:33-39 